\title{
'The Devil Is in the Details': On the Central Importance of Distinguishing the Truly Public from the Truly Private in Reconciling Equality and Religious Liberty
}

Ronald J. Krotoszynski Jr.

University of Alabama - School of Law, rkrotoszynski@law.ua.edu

Follow this and additional works at: https://scholarship.law.ua.edu/fac_working_papers

\section{Recommended Citation}

Ronald J. Krotoszynski Jr., 'The Devil Is in the Details': On the Central Importance of Distinguishing the Truly Public from the Truly Private in Reconciling Equality and Religious Liberty, (2019).

Available at: https://scholarship.law.ua.edu/fac_working_papers/588 


\section{HUGH F. CULVERHOUSE JR. \\ SCHOOL OF LAW THE UNIVERSITY OF ALABAMA}

"The Devil Is in the Details": On the Central Importance of Distinguishing the Truly Public from the Truly Private in Reconciling Equality and Religious Liberty

$$
\text { Ronald J. Krotoszynski, Jr. }
$$

RELIGIOUS FREEDOM, LGBT RightS, AND THE PROSPECTS FOR COMMON GROUND, Chapter 7

William N. Eskridge, Jr. \& Robin Fretwell Wilson, eds., (Cambridge University Press 2018)

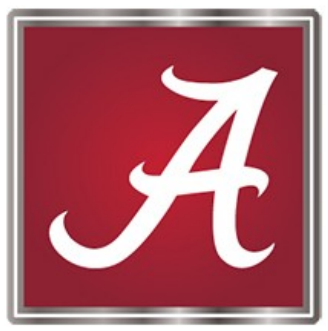

This paper can be downloaded without charge from the Social Science Research Network Electronic Paper Collection: https://ssrn.com/abstract $=3329376$ 


\title{
Religious Freedom, LGBT Rights, and the Prospects for Common Ground
}

\author{
Edited by \\ WILLIAM N. ESKRIDGE, JR. \\ Yale University \\ ROBIN FRETWELL WILSON \\ University of Illinois Urbana-Champaign
}


"The Devil Is in the Details"

\author{
On the Central Importance of Distinguishing the Truly Public \\ from the Truly Private in Reconciling Equality and \\ Religious Liberty
}

Ronald J. Krotoszynski, Jr.

In its 2016 report, Peaceful Coexistence: Reconciling Nondiscrimination Principles with Civil Liberties, ${ }^{1}$ the US Commission on Civil Rights (Commission) argues, in very strong terms, for the primacy of nondiscrimination rules over religiously motivated conscience claims. The Commission explains that "[c]ivil rights protections ensuring nondiscrimination, as embodied in the Constitution, laws, and policies, are of preeminent importance in American jurisprudence." ${ }^{2}$ And the Commission observes that "[r]eligious exemptions to the protections of civil rights based upon classifications such as race, color, national origin, sex, disability status, sexual orientation, and gender identity, when they are permissible, significantly infringe upon these civil rights." ${ }^{3}$ These observations will strike many as accurate and unobjectionable - but they tell us little, nothing in fact, about how to go about reconciling the competing fundamental human rights and values of equality and freedom of conscience.

Unfortunately, the Commission does not seem interested in reconciling competing fundamental human rights; it seeks instead to restrict religiously motivated expressive conduct that falls afoul of existing nondiscrimination laws and policies. More specifically, to the extent that the federal Religious Freedom Restoration Act (RFRA) or state-law equivalents might offer a defense against violations of nondiscrimination laws and policies, the Commission asserts that such exemptions should be narrowly construed - or even legislatively abolished - to protect only religious belief rather than conduct. It advocates this approach in order to ensure that such enactments "do not unduly burden civil liberties and civil rights protections against

1 U.S. Comm'n on Civil Rights, Peaceful Coexistence: Reconciling Nondiscrimination Principles with Civil Liberties (2016).

$=$ Id. at 25 .

3 Id. 
status-based discrimination."4 The Commission walks very close to the line of arguing that only belief - not conduct - should be protected in the context of public accommodation laws. ${ }^{5}$

Reconciling sincerely held religious convictions with federal, state, and local nondiscrimination laws cannot turn on a simplistic dichotomy between belief and conduct. This distinction has the potential effect of zeroing out protections for religious beliefs in any circumstance where a religious adherent attempts to share a religious belief with others. Taken to its logical conclusion, the belief/conduct dichotomy would permit a state government to punish actions taken to communicate religious belief.

For example, Marie and Gathie Barnette arguably engaged in "conduct" when they declined to participate in the Pledge of Allegiance. ${ }^{6}$ West Virginia's Board of Education did not require the Barnette girls to affirm their subjective belief or agreement with the Pledge of Allegiance; it merely required them to say the words as part of a daily morning ritual. So, too, a ban on "covering" in public, so long as the ban applies to all women within the jurisdiction, at least arguably would constitute a regulation of "conduct" rather than "belief." Muslim women would be quite free to maintain the belief that they should cover their heads when in public; they would simply lack the discretion to engage lawfully in conduct consistent with this belief.

If we are intellectually honest, then we have to concede that compelling interests exist on both sides of the ledger when claims of religious freedom come into conflict with public accommodation statutes. Any workable framework for sorting out the relative priority of religious liberty and freedom from status-based forms of discrimination must take this basic fact fully and fairly into account. As Section I explains, the belief/conduct framework constitutes a very poor mechanism for sorting out such claims. A focus on either third-party harm or proportionality analysis also suffers from serious shortcomings. ${ }^{7}$ Although no perfect framework exists, the public/ private distinction presents the most promising available framing device for resolving these conflicts, as Section II explains. Section III offers preliminary thoughts on how the public/private distinction might be utilized to better resolve conflicts between equality and religious liberty. Section IV concludes.

4 Id. at 27.

See id. at 25-27; see also id. at 29 (Statement of Chairman Martin R. Castro) (positing that '[t]he phrases 'religious liberty' and 'religious freedom' will stand for nothing except hypocrisy so long as they remain code words for discrimination, intolerance, racism, sexism, homophobia, Islamophobia, Christian supremacy or any form of intolerance" and arguing that " $t]$ his generation of Americans must stand up and speak out to ensure that religion never again be twisted to deny others the full promise of America")

6 West Virginia State Bd. of Educ. v. Barnette, 319 U.S. 624, 641-42 (1943).

See infra notes $20-31$ and accompanying text. 


\section{THE SUBSTANTIAL SHORTCOMINGS OF THE BELIEF/CONDUCT, THIRD-PARTY HARM, AND PROPORTIONALITY ANALYSIS \\ FRAMEWORKS}

The belief/conduct dichotomy does not do much, if any, real work in separating claims for religious exemptions that possess significant merit from those that do not. Because the expression of religious beliefs will inevitably involve conduct, the use of a belief/conduct dichotomy does not afford much protection to religious belief. Indeed, restricting the scope of religious liberty laws, and even the Free Exercise Clause itself, to privately held beliefs renders them virtually meaningless. Absent an ability to read people's minds, govemment can never be certain what subjective beliefs a citizen does or does not hold. If religious freedom is limited to the sphere of subjective belief, it will cease to exist.

Consideration of general free speech cases makes this point very clearly - expressive conduct counts as "speech" and may not be regulated freely because it annexes the communication of viewpoints and ideas to action. Thus, in Texas v. Johnson, the US Supreme Court had no difficulty in finding that flag burning constitutes "speech" and that a state law ban on flag burning constituted an unconstitutional, viewpoint-based regulation of speech. ${ }^{8}$ Justice William J. Brennan, Jr., writing for the majority, observed "that we have had little difficulty identifying an expressive element in conduct relating to flags should not be surprising" because " $[\mathrm{t}]$ he very purpose of a national flag is to serve as a symbol of our country." Although Texas characterized the mistreatment of a US flag as conduct and not speech, the Supreme Court emphatically held that burning a flag at a protest plainly constitutes speech $^{10}$ and reaffirmed this ruling a year later in United States $v$. Eichman. ${ }^{11}$

Other cases are consistent with this approach. Wearing a jacket emblazoned with "Fuck the Draft" in a public building constitutes speech and not mere conduct. ${ }^{12}$ Justice John Marshall Harlan swatted away the argument that Paul Cohen only engaged in conduct when wearing this jacket, wryly observing that "[t]he only 'conduct' which the State sought to punish is the fact of communication."'3 By way of contrast, Justice Harry Blackmun, writing in dissent, attempted to justify Cohen's prosecution and criminal conviction by arguing that "Cohen's absurd and immature antic, in my view, was mainly conduct and little speech." ${ }^{4}$ He added, for

84 U.S. 397, 411-13 (1989).

9 Id. at 405.

10 See id. at 420; see also Spence v. Washington, 418 U.S. 405, 409-11 (1974).

" 496 U.S. 310, 315-18 (1990). On the First Amendment's protection of expressive conduct more generally, see United States v. O’Brien, 391 U.S. 367, 377 (1968).

12 Cohen v. California, 403 U.S. 15, 16-18 (1971).

13 Id, at 18.

14 Id. at 27 (Blackmun, J., dissenting). 
emphasis, that because Cohen engaged solely in unprotected conduct, "this Court's agonizing over First Amendment values seems misplaced and unnecessary."

Individuals telegraph beliefs to others in large and small ways and do so constantly. What is more, individuals do this through conduct - through actions - as well as through words. The First Amendment's protection of expressive conduct as speech means that religiously motivated conduct constitutes an expression of belief.

Covering in order to honor a religious duty constitutes an expression of belief no less than burning a flag to protest the federal government's policies. Moreover, beliefs and actions are inextricably intertwined: Marie and Gathie Barnette not saying the Pledge of Allegiance; NFL 49ers quarterback Colin Kaepernik refusing to stand during the National Anthem and raising a "Black Power" fist after scoring a touchdown. ${ }^{16}$ Any public expression of belief will involve conduct of some sort, rendering it potentially unprotected under the First Amendment if government may regulate conduct with a relatively free hand.

Another side of the coin exists, however, and must be taken into account. Any action can be characterized as an expression of belief and therefore beyond the legitimate regulatory power of the state. Civil society simply cannot exist if groups within society, including self-constituted communities of faith, may be essentially self-regulating - and can decide which laws they will observe and which laws they will disregard. ${ }^{17}$ A position of absolute accommodation in the context of nondiscrimination laws also fails to credit fully and fairly the government's compelling interest in protecting members of minority groups from overt, often highly public, forms of discrimination. ${ }^{18}$ As Justice Brennan explained in Roberts $v$. United States Jaycees, "acts of invidious discrimination in the distribution of publicly available goods, services, and other advantages cause unique evils that government has a compelling interest to prevent - wholly apart from the point of view such conduct may transmit," and, in consequence, "like violence or other types of potentially

${ }^{15}$ Id.

16 Valerie Strauss, A Lesson On The Free-Speech Debate Colin Kaepernick Started, WASH. PosT (Sept. 26, 2017), https://perma.cc/N3RR-TCMH.

${ }^{17}$ See Reynolds v. United States, 98 U.S. 145, 166-67 (1878) (observing that excusing a man's practices because they are contrary to his religious belief "would be to make the professed doctrines of religious belief superior to the law of the land, and in effect to permit every citizen to become a law unto himself. Government could exist only in name under such circumstances.").

${ }^{18}$ See Roberts v. United States Jaycees, 468 U.S. 609, 623-25, 628-29 (1984) (holding that application of the Minnesota Human Rights Act forbidding discrimination on basis of sex in "places of public accommodation" to the Jaycees, requiring them to admit women to local chapters in Minnesota, did not abridge male members' freedom of intinate or expressive association); Bob Jones Univ. v. United States, 461 U.S. 574, 575, 592-96 (1983) (upholding denial of tax-exempt status to a nonprofit private school that prescribed and enforced racially discriminatory admission standards on the basis of religious doctrine on the grounds that the school did not meet two common-law standards of a charity, "namely, that an institution seeking tax-exempt status must serve a public purpose and not be contrary to established public policy"). 
expressive activities that produce special harms distinct from their communicative impact, such practices are entitled to no constitutional protection. ${ }^{m 9}$

Permitting persons of faith to characterize any and all actions as manifestations of belief invites totalizing claims that would potentially render nugatory virtually all major civil rights enactments. For example, had complicity-based exemption claims enjoyed widespread cultural, political, and legal salience in the mid-196os, Ollie's $B B Q$, in Birmingham, Alabama, could easily have justified operating its dining room on a racially segregated basis by invoking a religious basis for its racially discriminatory policies. ${ }^{20}$ Other businesscs across the Deep South would have adopted this strategy in quick succession, thereby utterly defeating Title II of the Civil Rights Act of 1964. Religiously based justifications for segregation were widespread in the South, both before and after the Civil War; indeed, advocates of human chattel slavery routinely justified the practice by invoking biblical references. ${ }^{21}$

In sum, the belief/conduct dichotomy will not provide clear, predictable answers in hard cases - an essential condition for securing peaceful coexistence. The Commission's understanding of "peaceful coexistence" requires unilateral surrender by those who seek to communicate their beliefs to others through their words and actions. At the same time, however, the dissenting commissioners are equally mistaken when they advocate sweeping exemptions to neutral laws of general applicability, notably including public accommodation laws. ${ }^{22}$

Some members of the contemporary Supreme Court have suggested that thirdparty harm demarks when a generalized protection for religious practice like RFRA should no longer provide a shield against a neutral law of general applicability that advances a compelling government interest. ${ }^{23}$ Thoughtful legal academics also have

19 Roberts, 468 U.S. at 628 ; see also Bob Jones Univ., 461 U.S. at 592 (observing that "there can no longer be any doubt that racial discrimination in education violates deeply and widely accepted views of elementary justice").

20 See generally Katzenbach v. McClung, 379 U.S. 294, 296-98 (1964).

See Alfred L Brophy, Universtty, Court, and Slave: Pro-Slavery Thought in Southern Collegers ANd Courts AND the Coming of Civil War (2016); see also William N. Eskridge Jr., Noah's Curse: How Religion Often Conflates Status, Belief, and Conduct to Resist Antidiscrimination Norms, 45 GA. L. REv. 657, 665-72 (201) (tracing the evolution of religious justifications for both slavery and Jim Crow, observing that "religious leaders ... deployed Bible-based arguments to support the notion that the Word of God sanctioned the slavery of Africans," notably including "Noah's Curse," which "provided an authorization for the enslavement of the descendants of Ham (Africans taken to the American colonies) to the descendants of Japheth (the English colonists)"). Professor Eskridge notes that "[e]ven after the Thirteenth Amendment, adopted in 1865 , abolished slavery, some religious leaders continued to invoke biblical arguments for slavery, but increasingly, southern religious leaders modemized Noah's Curse to address the post-slavery environment." Id. at $66 \%$.

${ }_{22}$ U.S. Comm'N ON CiviL Rights, supra note 1, at 42. (Commissioner Peter Kirsanow's rebuttal); id. at 115 (Commissioner Gail Heriot's rebuttal).

23 See Hobby Lobby v. Burwell, 134 S. Ct. 2751, 2799-2801 (2014) (Ginsburg, J., dissenting).

endo:

Thirc valid prese

As

esote

any 1

causi

ized:

the $\mathrm{p}$

a this

such

use $c$

Cc

head

legisl

perce

wom

impo

advas

are a

priate

speer

flags

the $\mathrm{i}$

but I

whits

${ }^{24} \mathrm{Set}$

Co

ina

${ }^{25}$ Prc

tha

be

a t

acs

${ }_{26} \mathrm{Te}$

${ }^{27} \mathrm{Sn}$

54

$28 \mathrm{Ser}$

of

IN

${ }^{29} \mathrm{Ser}$ $\mathrm{Ch}$ 
municative

ifestations of virtually all ption claims 960s, Ollie's ig its dining $r$ its racially would have itle II of the I were wideadvocates of ing biblical

able answers istence. The ral surrender ir words and are equally 's of general

ed that thirdse like RFRA licability that nics also have

re can no accepted

N South'illiam N. t to Resist $\mathrm{f}$ religious deployed he slavery in for the es) to the :] ven after aders conus leaders ; rebuttal); เting). endorsed this approach, including Doug NeJaime and Reva Siegel in this volume. ${ }^{24}$ Third-party harm is, admittedly, an attractive way of trying to draw the line between valid and invalid claims to religious accommodations. However, third-party harm presents its own pathologies.

As with the belief/conduct dichotomy, third-party harm is potentially a rather esoteric concept. Third-party harm often lies in the eye of the beholder. Virtually any religiously motivated conduct could be characterized as causing, or not causing, third-party harm. This is so because offense can be - and is - characterized as a third-party harm. ${ }^{25}$ Justice John Paul Stevens, for example, characterized the profound offense that veterans experience when subjected to flag burning as a third-party harm sufficient to justify criminalizing flag burning. ${ }^{26}$ So too, torts such as intentional infliction of emotional distress and intrusion upon seclusion use offense - outrageousness - as a basis for imposing civil liability. ${ }^{27}$

Consider once again a legislative ban on women covering their faces with headscarves. Localities in France that banned "burkinis" did not justify this legislation on the basis of hostility toward Islam, but rather on the basis of a perceived third-party harm. ${ }^{28}$ The argument goes something like this: When women cover in public places, such as beaches, they convey a message of selfimposed gender subordination that conflicts with France's public policy of advancing the equality of the sexes; girls who see women covering in public are arguably harmed because they might internalize a message that it is appropriate for women to self-subordinate themselves in public. This concept of speech creating a third-party harm also explains the ban on Confederate battle flags at several SEC university stadiums; university administrators wish to avoid the infliction of third-party harms on those who experience not merely offense, but psychological harm, when exposed to this emblem synonymous with racist white power ideology. ${ }^{29}$

${ }^{24}$ See NeJaime \& Siegel, Chapter 6; Douglas NeJaime \& Reva B. Siegel, Conscience Wars: Complicity-Based Conscience Claims in Religion and Politics, 124 YALE L.J. 2516 (2015) [hereinafter Conscience Wars].

${ }^{25}$ Professors Nejaime and Siegel define "third party" harm in careful terms; this is not to suggest that the concept lacks any utility in deciding which clains to religious accommodation should be credited. See id. at 2519, 2529-33, 2580-86. Nevertheless, the concept is not self-defining and a broad definition of third-party harn would essentially require the rejection of all claims to accommodations.

${ }^{26}$ Texas v. Johnson, 491 U.S. 397, 437-39 (1989) (Stevens, J., dissenting).

${ }^{27}$ Snyder v. Phelps, 562 U.S. 443, 458-59 (2011); Hustler Magazine, Inc. v. Falwell, 485 U.S. 46, 54-55 (1988); RESTATEMENT (SECOND) OF TORTS \$ 652B (AM. LAW INST. 1977).

${ }_{28}$ See generally Asma T. Uddin, Religious Modesty for Women and Girls: A Comparative Analysis of Legal Protections in France and the United States, in The Contested Place of Relicion IN FAMILY LAW 308 (Robin Fretwell Wilson ed., zo18).

${ }^{29}$ See, e.g., Bob Carlton, Former Ole Miss Chancellor Talks About How Confederate Flag Ban Changed a Culture, AL.com (Oct. 29, 2013), https://perma.cc/Z3 $\mathrm{G}_{3}$-SAVY. 
To be sure, the First Amendment imposes limits on the ability of civil juries to impose liability for offensive or outrageous speech. ${ }^{3 \circ}$ But even pure speech can engender liability without violating the First Amendment - a plaintiff may establish a hostile work environment claim based entirely on speech. To be actionable, the speech must create a pervasively oppressive environment. Nevertheless, speech that creates an environment intolerable to a reasonable woman, person of color, or religious believer may be proscribed. ${ }^{31}$

Because a broad application of a third-party harm doctrine could prohibit the expression of beliefs that are offensive to others, drawing a line using a theory of third-party harm risks providing insufficient protection for the public expression of religious belief. For example, a polity strongly committed to full marriage equality could deem public expressions of support for the traditional, lielerosexual nuclcar family to constitute impermissible hate speech that produces an unacceptable risk of imposing third-party harm on families helmed by a same-sex couple. If a business posts a sign saying "We Support Traditional Family Values," but also serves all comers on identical terms, liability for a constructive denial of service should not exist. But if the state deems the public expression of support for traditional heterosexual families to demean or marginalize nontraditional families, thereby producing third party harm, a government civil rights agency could impose liability for nothing more than the public expression of a religiously motivated, sincerely held belief. ${ }^{32}$

If third-party harm is to work as a means of cabining the scope of religious accommodations, the universe of harms to be recognized must be limited to avoid potentially creating liability for the public expression of religious ideas and beliefs. The kinds of third-party harm that justify withholding religious accommodations need to be defined with particular care so as to provide sufficient breathing room for speech and expressive conduct. Thus, although plainly preferable to the belief/ conduct dichotomy, using third-party harm as a framing device will not reliably produce clear answers in hard cases.

$3^{\circ}$ See Snyder, 562 U.S. at 458-61 (prohibiting liability against the Westboro Baptist Church for outrageously offensive speech involving a targeted funeral protest of a dead soldier killed while on active duty). Justice Samuel Alito would have permitted the civil jury verdict against Westboro Baptist Church to stand. See id. at $46_{3}$ (Alito, J., dissenting).

${ }^{31}$ See Meritor Savings Bank v, Vinson, 477 U.S. 57, 64-68, 72 (1986). Some First Amendment scholars object to hostile work environment liability precisely because it can create civil liability for speech alone. Kingsley R. Browne, Titte VII as Censorship: Hostile-Environment Harassment and the First Amendment, $5_{2}$ OHo Sr. L.J. 481 (1991); Eugene Volokh, How Harassment Law Violates Free Speech, 47 Rutcers L. Rev. $5^{6} 3$ (1995).

32 But cf. U.S. COMm'N ON Civil Richis, supra note 1, at 25-27 (proposing a scope of liability under federal and state nondiscrimination laws that would arguably encompass mere statements of religious belief if those statements arguably reflect discriminatory viewpoints); id. at 29 (Statement of Chairman Martin R. Castro) (arguing that discriminatory points of view should not be tolerated and that "any forn of intolerance" should be subject to government regulation). 
juries to zech can establish able, the sech that color, or

hibit the theory of :ession of : equality 1 nuclear ble risk of business serves all rould not al heterosoducing is nothing belief. $^{32}$ religious I to avoid Id beliefs. nodations ; room for he belief/ st reliably
Proportionality analysis, a widely adopted device in much of the democratic world, might seem a promising approach to reconciling equality principles with religious liberty. ${ }^{33}$ Proportionality analysis requires a rights claimant to invoke the right successfully at step one and then permits the entity violating the right to attempt to justify the burden at step two. ${ }^{34}$ If a burden or restriction on the exercise of a right advances sufficiently important goals and objectives, the regulation may be applied even though it burdens a fundamental right (such as freedom of conscience). In Canada, South Africa, and the jurisprudence of the European Court of Human Rights, proportionality analysis is entirely quotidian. ${ }^{35}$

An obvious problem exists with adopting proportionality analysis as a sorting mechanism: proportionality analysis will not produce predictable results across a wide range of disputes. The relative equities of a person seeking to invoke rights of conscience to deny service and a person seeking to obtain services free and clear of targeted discrimination are highly subjective. Within this volume, for example, some would weight the interests of religious objectors more heavily, whereas others would see burdens upon them as in service of more pressing values. ${ }^{36}$ This subjectivity has particularly pernicious implications for religious liberty claims because members of unpopular or "oddball" religious sects will find their claims routinely rejected whereas similar claims brought by members of more culturally familiar religions will prevail. ${ }^{37}$ Thus, proportionality analysis too often will redound to the detriment of unpopular religious minorities when government agencies and courts seek to reconcile demands for specific accommodations with the imperatives of generally applicable nondiscrimination rules. Further, as Americans increasingly move away from organized religion, even more mainstream sects may find their interests given short shrift. ${ }^{8}$ In the end, then, proportionality analysis is too openended and subjective to provide a workable solution.

However, the public/private distinction, the application of which involves a more limited form of proportionality analysis, might provide a workable solution. The analysis would not involve separating belief from conduct, or assessing third-party harm, but rather would seek to disentangle the truly public from the truly private. Self-constituted communities of faith are inherently private in nature and should not be subject to pervasive forms of state regulation - even to advance a cause as

33 See Vicki C. Jackson, Constitutional Law in the Age of Proportionality, 124 YALE L.J. 3094, 3096 (2015); Vicki C. Jackson, Being Proportional About Proportionality, 21 Const. COMMENT. 803 804-07 (2004).

34 See R, v. Oakes, [1986] i S.C.R. 103, 135-40 (Can.); see also David M. Beatty, The Ultimate RULE OF LAW $163-68$ (2004).

35 Ronald J. Krotoszynski, Jr., Privacy Revistted: A Global. Persplective on the Right to BE LEFT ALONE 148-50 (2016).

${ }^{36}$ See Laycock, Chapter 3; Smith, Chapter 18; Melling, Chapter 19.

37 See Ronald J. Krotoszynski, Jr., "If Judges Were Angels": Religious Equality, Free Exercise, and the (Underappreciated) Merits of Smith, 102 Nw. U.L. REv. 1189, 1235-43, 1261-62 (2008).

$3^{8}$ See generally Pew Restarch Ctr., America's Changing Religious Landscape (2015). 
important as equality. ${ }^{39}$ "The structure of the federal Civil Rights Act and state nondiscrimination laws reflect this supposition, routinely leaving aside private clubs and associations. ${ }^{40}$ On the other hand, however, status-based denials of service based on one's identity are stigmatizing and degrading; members of minority groups should not be taken by surprise at the grocery store checkout line. This approach, as explained later in this chapter, would involve a careful, contextual analysis of the fundamental nature of the entity seeking an exception from a nondiscrimination law or policy.

II TOWARD A MORE WORKABLE FRAMEWORK BASED ON THE

\section{PUBLIC/YRIVATE DISTINCTION}

Drawing an effective boundary line requires a framing device that does real work that permits the predictable sorting of claims that justify an exemption from those that do not. Predictability and ease of application are necessary attributes because in this context, uncertainty will produce severe chilling effects on the expression of religious belief. ${ }^{41}$ It also leaves minorities vulnerable to unexpected, and stigmatizing, denials of service at businesses that ostensibly serve all comers. Thus, discretion needs to be constrained in both directions - and constrained in predictable ways. ${ }^{42}$ The question then becomes: What means would best permit the sorting of claims in a predictable way?

Case law involving more general freedom of association claims provide a doctrinal framework that could be redeployed in the context of religious accommodation claims - whether brought under the Free Exercise Clause itself or a RFRA-type

39. Hosanna-Tabor Evangelical Lutheran Church \& School v. EEOC, 565 U.S. 171, 188-93 (2012); John D. Inazu, Liberty's Refuge: The Forcotten Freedom of Assembly 13, 167-76, 185-86 (2012) (arguing that private, noncommercial self-constituted groups should enjoy a broad freedom to choose their fellow travelers even using discriminatory metrics)

$4^{\circ}$ See, e.g., 42 U.S.C. $\int 12187$ (2017); Wis. Stкт. S 106.52(3)(e) (2015).

${ }^{41}$ If a reasonable person does not know when she can invoke the First Amendment as a shield against liability for violating a nondiscrimination law, the prudent response would be to selfcensor speech and behavior to avoid incurring civil liability. The interest in clear rules that produce predictable results also benefits those protected by nondiscrimination enactments; clear rules would permit members of protected minority groups to avoid the embarrassment or humiliation that accompanies a denial of service based on their identity. Clear rules regarding the scope of exemptions thus redound to the benefit of both religionists and minority group members.

42 To be sure, predictability is not an absolute value in and of itself - after all, "predictability" could be achieved by adopting a legal rule that ignores either nondiscrimination or religious liberty values by zeroing out completely one interest or the other. This would not constitute a just or reasonable approach - but it would certainly advance the cause of predictability. Nevertheless, in the context of setting a principled and reasonable balance, predictability constitutes a signal virtue (and not a vice) because it permits both religious believers and members of minority communities to make informed decisions about how to live their lives in ways that maximize their autonomy and freedon. 
and state ate clubs ice based y groups ipproach, isis of the ation law

$\mathrm{HE}$

eal work rom those because in ression of I stigmatizdiscretion ble ways. ${ }^{42}$ of claims in

Je a doctrinmodation RFRA-type

; (2012); $167-76$, enjoy a statute. Decisions such as Roberts $v$. United States Jaycees ${ }^{43}$ and New York State Club Association ${ }^{44}$ would parse claims on the basis of the nature of the institutions seeking to claim an accommodation from a generally applicable nondiscrimination rule. Under the constitutional logic of these precedents, institutions that do not hold themselves out as open and available to the general public possess a considerably stronger claim to operate in idiosyncratic ways than institutions (whether religious in character or not) that purport to be open and available to any and all persons. ${ }^{45}$ To state the matter in another way, if exclusion is essential to the identity of an institution and to its very raison d'être, then its rules and behavior should reflect these facts. A society of cloistered nuns does not typically operate a hamburger stand on the public square - or provide the general public with unfettered access to its convent. A McDonald's restaurant or Walmart store, by way of contrast, goes out of its way to signal "we are open to and will serve anyone who wishes to buy our goods." These, then, constitute the two poles of the truly private (a cloistered convent) and the truly public (a McDonald's restaurant or Walmart store).

The public/private distinction aligns nicely with the animating purposes and goals of nondiscrimination laws. When a religious organization denies nonadherents access to its rites, the exclusion does not impose a dignitarian harm; it does not stigmatize. The fact that exclusion based on nonmembership in a faith community is nontargeted prevents or, at the least, significantly muffles the dignitarian harm; even if all members of a particular minority are excluded from membership in a church, a great number of nonminorities are excluded as well. Sussing out the precise reasons for exclusion involves a considerably more complex analysis than when a store otherwise open to the general public displays a sign stating that it will not serve LGBT persons (where the only explanation can be animus). Alternatively, to the extent that exclusions from membership in a religious community might be stigmatizing in some respects, society reflexively deems the social harm justified in the name of permitting the self-constituted community of faith to maintain the tenets of its faith. ${ }^{46}$

The harms that public accommodation laws seek to forestall are dignitarian in nature, namely the unfair surprise of finding that one's money will not spend in a store otherwise open to everyone else. As Chief Justice Earl Warren explained in Brown v. Board of Education, ${ }^{47}$ status-based discrimination, in the form of exclusion,

${ }^{43} 468$ U.S. $609,623-29(1984)$.

44 New York State Club Ass'n, Inc. v. City of New York, 487 U.S. 1, 12-14 (1988).

45 Of course, one could object that conduct motivated by religious conviction is special and merits a broader scope of protection than conduct motived by an economic, scientific, moral, ideological, or political belief. This objection, however, relates more to the strength of the private interest than to the potential utility of using the public/private distinction as the appropriate doctrinal framework for sorting religious accommodation claims.

${ }^{66}$ Hosanna-Tabor Evangelical Lutheran Church \& School, 565 U.S. at 188-90, 194-96.

47347 U.S. 483 (1954). 
is humiliating and imposes serious psychological harms. ${ }^{48}$ Deterring and remediating harms of this sort constitute the lodestar of our nondiscrimination laws.

Denials of service in places and spaces generally open to the public are inherently stigmatizing; ${ }^{49}$ on the other hand, however, denials of service by entities that are not generally open to any and all comers are not. Whether framed in terms of a lack of dignitarian harm or in terms of the legitimate autonomy claims of a faith community, the religious group's claim to be free from government regulation trumps the interest of a person excluded based on her identity or belief. ${ }^{\circ}$ A concrete example will help to demonstrate the relevant distinction.

If a person applies to teach at a madrassa (or Islamic religious academy), and she is not Muslim, she should not be surprised to have her application for a teaching position rejected. The Court in Hosanna-Tabor Evangelical Lutheran Church G School $v$. EEOC embraced the logic of this position, in the form of a ministerial exemption for instructional staff at a church-operated school. ${ }^{51}$ Consistent with an approach that exempts truly private entities from general nondiscrimination laws, an accommodation for employment-related policies should be extended beyond the teaching staff to all positions in the school - even the custodial staff. A community of faith operating a school should be able to employ a staff that shares the faithcommitment that the school exists to inculcate and advance..$^{22}$

Nor should the nature of the screening device - discrimination - matter. When a pervasively religious private entity screens for coreligionists, a wide variety of

${ }^{48}$ Id. at 494 ("To separate them from others of similar age and qualifications solely because of their race generates a feeling of inferiority as to their status in the community that may affect their hearts and minds and minds in a way unlikely ever to be undone."); see Chai Feldblum, Moral Conflict and Conflicting Liberties, in Same-Sex Marriage and Relrgrous Liberty: Emerging Conflicts 123, 153 (Douglas Laycock, et al. eds., 20o8) (arguing that stahus-based denials of service impose significant psychological harms); NeJaime \& Siegel, Conscience Wars, supra note 24, at 2566-78 (documenting the harms associated with excusing general legal obligations, such as nondiscrimination rules, based on the concept of complicity).

49 Regents of the Univ. of Cal. v. Bakke, 438 U.S. $265,324,361-62,374$ (1978) (Brennan, J., concuming in part and dissenting in part) (arguing that "any statute must be stricken that stigmatizes any group or that singles out those least well represented in the political process," even if the statute was intended to benefit nembers of minorily groups who suffered from legally sanctioned discrimination in the past); United Jewish Orgs, v. Carey, 430 U.S. 144, 173-74 (1977) (Brennan, J., concurring) (positing that when an affirmative action program has the effect of stigmatizing those it seeks to benefit, it violates the Equal Protection Clause).

5o See Ira C. Lupu \& Robert W. Tuttle, The Mystery of Unanimity in Hosanna-Tabor Evangelical Lutheran Church \& School v. EEOC, zo LewIS \& CLARK L. Rev. 1265, 1280-92 (2017).

${ }^{52}$ Hosanna-Tabor Evangelical Lutheran Church \& School, 565 U.S. at 194-96; see Lupu \& Tuttle, supra note 50 , at $1280-84$.

52 Whether Title VII's protections allowing religious employers and universities to hire on the basis of religion authorizes them to legally make religiously based distinctions that implicate collateral protected grounds such as sex, or relatedly, sexual orientation or gender identity, is the subject of considerable debate. See generally Robin Fretwell Wilson, Squaring Faith and Sexuality in Religious Institutions: The Unique Challenge of Sports, 34 L. \& INEQ. $3^{85}$ (2016).

cha

for 1

as a

ems

base

Cur

stigr

the

ciler

$\mathrm{U}$

relig

exan

Holy

not

cons

Ar

most

relig

entit

othe:

whet

avoic

coms

53 Set

del

for

54 See

abs

per

offt

Iea

we

alte

eral

55 See

A C

abo

Cla

requ

loce

saci

${ }^{6} \mathrm{See}$

prol

the

judi 
ing and remediatation laws.

blic are inherently intities that are not i terms of a lack of of a faith commuulation trumps the concrete example

:ademy), and she is ion for a teaching itheran Church \& m of a ministerial Consistent with an rimination laws, an ended beyond the ff. A community of it shares the faith-

. - matter. When a

a wide variety of

iolely because of $y$ that may affect ne."); see Chai 玉 AND Religious 28) (arguing that Jaime \& Siegel, ed with excusing the concept of

78) (Brennan, J., : be stricken that colitical process," ho suffered from ey, 430 U.S. 144 , :tion program has ction Clause).

Pabor Evangelical $30-92$ (2017).

-96; see Lupu \&

ies to hire on the uns that implicate zender identity, is puaring Faith and INEQ. 385 (2016). characteristics and attributes could potentially lead to targeted forms of exclusion for example, a promiscuous heterosexual lifestyle could be a basis for rejection, just as a total lack of interest in procreative marital sex might be a basis for exclusion from employment. Some forms of exclusion might be based on behavior; others might be based entirely on mere status. For example, if a religious sect took seriously "Noah's Curse,"53 it might exclude people of color from membership. This would be stigmatizing to those excluded, but the alternative would be for the state to regulate the rules of membership for churches. Such an outcome simply cannot be reconciled with a meaningful commitment to the freedom of religious belief. 54

Under the logic that the state may extirpate any and all forms of discrimination, religious organizations could be forced to violate core doctrines of the faith - for example, the Roman Catholic Church's absolute reservation of the sacrament of Holy Orders (i.e., consecration as a priest) to men. ${ }^{55}$ Such an outcome should be, if not unthinkable, then close to it in a society that purports to enshrine freedom of conscience as a core human rights value.

Accordingly, a self-constituted community of faith, hiring for a church, temple, or mosque, or a school annexed to a church, temple, or mosque, should be able to use religiously motivated metrics to hire and fire its staff. Aren't all religious beliefs entitled to equal respect and concern $?^{56}$ To validate some screening rules but not others is to validate some religions but not others. An institutional analysis that asks whether the enterprise is entitled to an exemption from public accommodation laws avoids the embarrassment, and constitutional infirmity, of deciding which religious commitments merit respect and consideration - and which do not.

53 See Eskridge, supra note 21, at 665-78 (discussing "Noah's Curse" and its commonplace use to defend and support the maintenance of human chattel slavery and also de jure and de facto forms of racial segregation in the United States).

54 See United States v. Ballard, 322 U.S. 78, 94-95 (1944) (Jackson, J., dissenting) (arguing for absolute constitutional protection for religious beliefs, however benighted or bizarre from the perspective of the dominant religious sects within the community, because freedom of even offensive or outlandish religious belief "is precisely the thing the Constitution put beyond the reach of the prosecutor, for the price of freedom of religion or of speech or of the press is that we must put up with, and even pay for, a good deal of rubbish" and cautioning that an alternative approach, permitting government to regulate religious beliefs, "easily could degenerate into religious persecution").

55 See Ronald J. Krotoszrnski, Jr., The First Amendment in Cross-Cultural Perspective: A Comparative Legal Analysis of the Freedom of Speech 99 (2006) (noting that the abolition of the state action doctrine could lead to efforts to enforce the Equal Protection Clause against entities such as the Roman Catholic Church, and federal courts "would be required to weigh [a group] of nuns' interest in being free of gender discrimination against [the local] bishop's interest in enforcing the doctrines of the Roman Catholic Church regarding the sacrament of Holy Orders").

56 See Ballard, 344 U.S. at 93-95 (Jackson, J., dissenting) (arguing for the robust constitutional protection of even highly unorthodox and controversial religious beliefs and positing that under the Free Exercise Clause, the federal courts should scrupulously avoid the "business of judicially examining other people's faitls"). 
In sum, denials of service by intrinsically and pervasively private entities do not demean or stigmatize those denied service in the same way, or to the same degree, as denials of service by entities open to the public. Denials of service by entities that hold themselves out as generally open to any and all persons impose serious dignitarian harms. Thus, the relevant questions that must be asked and answered are: (1) To what extent does the entity or business hold itself out as open to all comers?; and alternatively, (2) To what extent does it telegraph, "We choose our fellow travelers"? An entity that holds itself out as private should be entitled to claim exemptions from public accommodation enactments; by way of contrast, an entity generally open to the public should not. ${ }^{57}$

One should bear in mind that the public or private character of an entity should not be a function of its physical location. Instead, the character or nature of the actor should determine its public or private status. We need to think of "public" and "private" in associational, not physical, terms. For example, a K-12 school operated by a religious community is private, even if the school building sits on the town's main public square. A small bookstore in a Catholic cathedral is private, not public. By way of contrast, a McDonald's fast-food restaurant or Books-A-Million store is public, as are an Olan Mills photography studio and an Arthur Murray dance schonl. ${ }^{58}$

Of course, hard cases will exist. Could a Catholic hospital refuse to recognize a same-sex couple as the parents of a newborn? Or could the hospital treat a same-sex spouse as a third party for all intents and purposes, including visitation privileges? Refusing to credit a legally valid civil marriage is likely a bridge too far, particularly if the hospital operates an emergency room or participates in preferred provider networks and so receives patients who do not make a conscious choice to patronize

57 Ronald J. Krotoszynski, Jr., Agora, Dignity, and Discrimination: On the Constitutional Shortcomings of "Conscience" Laws That Promote Inequality in the Public Marketplace, zo LEwIs \& Clark L. Rev. 1221, 1234-39 (2017) [hereinafter Agord].

${ }^{8}$ By definition, a business operated on a franchised basis will never possess the characteristics necessary to render it "private." After all, the owners have ceded control over central aspects of the business to a third party, with the expectation that the business will be operated in lockstep fashion with others operating under the same brand name. Ceding control of the manner in which a business operates to a third party severely undermines an owner's (franchisee's) claim that her business operation constitutes an exercise in highly personalized expressive conduct. Even franchise operations, such as Chick-fil-A, that tend to attract co-venturers that maintain a common religious, political, or ideological sensibility, invariably require franchisees to follow a set template for their aperations. Moreover, the principal objective is to win sales - rather than converts. See Timothy Egan, Conscience of a Corporation, N.Y. Trmes (Apr. 3, 2015), http:// nyti.ms/1M)rdBT (noting that Chick-fil-A has a corporate nondiscrimination policy with respect to sexual orientation that it adopted "[a]fter condemning same-sex marriage and becoming a culture-war battleground"). In this regard, it bears noting the Chick-fil-A corporate policy prohibits status-based discrimination by franchisees; Chick-fil-A serves anyone and everyone with cash in hand to make a purchase. See Krotoszynski, Agora, supra note 57, at 1257-58 n.141. Moreover, "there are no reported incidents of Chick-fil-A seeking to discriminate against LGBT customers or employees." Id. at 1258 n.141.

the fa requir the ste service to tho:

The F coexis in this and to

Firs constit religio places the a comm Seci Serve service "conse to the sort to open author

59 Ther trans Helf: L. R:

6. Moo "stats are $v$

61 See

62 See I wher Mar in $\mathrm{Cr}$ custe 
entities do not ame degree, as by entities that mpose serious and answered as open to all Ve choose our atitled to claim trast, an entity

n entity should ure of the actor f "public" and chool operated ; on the town's ate, not public. Villion store is Murray dance

to recognize a reat a same-sex tion privileges? $r$, particularly if ferred provider ce to patronize

ional Shortzo LEWIS \&

aracteristics al aspects of I in lockstep : manner in see's) claim ve conduct. $t$ maintain a $s$ to follow a rather than :015), http:// policy with arriage and - A corporate inyone and note 57 , at tiscriminate the facility. ${ }^{59}$ Moreover, many states regulate the provision of medical services, requiring a certificate of need in order to open a new health care facility. When the state limits market entry, and vests a license with a pervasively discriminatory service provider, the actions have the effect of denying access to goods and services to those the enterprise will not serve. ${ }^{60}$

\section{SOME PRELIMINARY THOUGHTS ON DEPLOYING THE PUBLIC/ PRIVATE DISTINCTION TO RESOLVE CONFLICTS BETWEEN EQUALITY AND RELIGIOUS LIBERTY}

The public/private distinction constitutes the most promising route to peaceful coexistence. It is not possible to work out all the details - the bells and whistles in this short chapter. Nevertheless, it is possible to sketch out some frst principles and to address a few potential objections.

First, religious belief should be vigorously protected, whether as a matter of constitutional or statutory law, and should include conduct intended to convey religious belief. This protection should extend to conduct in public spaces and places. Protection of belief also should require searching consideration of laws and the application of laws potentially motivated by animus toward a faith community. $^{61}$

Second, a McDonald's or Jiffy Lube should not be permitted to post "We Do Not Serve Homosexuals" signs in their businesses even if the owners wish to refuse service to LGBT customers because of a sincerely held religious belief. ${ }^{62}$ State "conscience" laws, such as Mississippi's H.B. 1523, would permit businesses open to the public to engage in comprehensive forms of discrimination. ${ }^{6}$ Efforts of this sort to attach formal legal sanction to targeted forms of discrimination by businesses open to the public violate the Equal Protection Clause. ${ }^{64}$ 'The state's ability to authorize third-party harms through positive law is not infinite and the state must

59 There is clearly no "implied consent" when a person suffering a medical emergency is transported to a religiously identified trauma center. Cf. Helfand, Chapter 11; Michael A. Helfand, Religious Institutionalism, Implied Consent, and the Value of Voluntarism, $88 \mathrm{~S}$. CAL. L. Rev. 539 (2015).

6o Moose Lodge No. 107 v. Irvis, 407 U.S. 163, 182-83 (1972) (Douglas, J., dissenting) (arguing that "state-enforced scarcity of licenses" implicates the Equal Protection Clause when such licenses are vested with discriminatory service providers).

61 See generally Church of the Lukumi Babalu Aye, Inc. v. City of Hialeah, 508 U.S. 520 (1993).

${ }^{6}$ See INAZU, supra note 39 , at 13 (positing that "antidiscrimination norms should typically prevail when applied to commercial entities"). But cf. Douglas Laycock, Aftenword, in SAmE-SEx MARRIAGE AND RELIGIOUS LiBERTY, supra note 48, at 198-200 (advocating the posting of signs in commercial businesses indicating to the public that a business does not serve LGBT customers),

$6_{3}$ Krotoszynski, Agora, supra note 57, at 1225-26, 1239-45.

${ }^{6}$ Id. at $1245-49$. 
not seek to do indirectly that which the Equal Protection Clause forbids it to do directly. ${ }^{65}$

Third, the availability of exemptions for religiously motivated denials of service should depend, at least in part, on the reasonableness of the refusal of service taken in context - much as free association claims turn on the entity that seeks to invoke the First Amendment as a shield clearly establishing a link between the association's core reasons for existing and the exemption it seeks from a nondiscrimination law. ${ }^{66}$ To what extent does the entity seeking the exemption telegraph that it picks and chooses those it will serve based on the precepts of a particular faith tradition? The question of surprise - of ambush - should be front and center in this contextual analysis. When a business signals that it is open to any and all persons, it is a "public" enterprise and should be subject to comprehensive regulation that promotes the health, safety, welfare, and morals of the community. ${ }^{67}$

Fourth, and finally, the requisite analytical exercise should bear some resemblance to ferreting out state action. The state action doctrine uses a careful, contextsensitive approach to identify the circumstances that justify treating an ostensibly private entity as the state itself - and imposing constitutional obligations on the entity as a consequence. 'l'he federal courts inquire into the nature of the activity at issue (is it an exclusive government function, like conducting elections for public office, that the government has delegated to an ostensibly private entity?), the interrelationship of the government and the ostensibly private entity (a coffee shop operating in a county courthouse building stands on different state action ground than a coffee shop not located in a government edifice), whether the government has encouraged behavior that it cannot directly command via regulation

${ }^{6} 5$ See Reitman v. Mulkey, 387 U.S. 369, 372-77, 380-81 (1967); see also NeJaime \& Siegel, Conscience Wars, supra note 24, at 2519 (noting that laws creating broad, complicity-based exemptions "are explicitly oriented toward third parties, [and] they present special concerns about third-party ham").

66 Boy Scouts of America v. Dale, 530 U.S. 640 (2000); Hurley v. Irish-American Gay, Lesbian \& Bisexual Group of Boston, 515 U.S. 557 (1995); New York State Club Ass'n, Inc. v. City of New York, 487 U.S. 1 (1988); see INAZU, supra note 39, at 175 (arguing that although "there is much to be said for an antidiscrimination norm and the value of equality that underlies it," we must also keep in mind that "our constitutionalism also recognizes values other than equality, including a meaningful pluralism that permits diverse groups to flourish within our polity").

${ }_{7}$ Of course, nothing requires a bakery otherwise open to the public to sell personalized wedding cakes to anyone. If a business owner wishes to limit the goods or services that she offers to the public because of her religious beliefs - and to do so comprehensively - nondiscrimination laws should not come into play. We do not have a legal or social history, save in highly regulated industries, such as health care, of regulating a business's scope of operation. Thus, a photographer could decline to shoot any weddings - and such a policy should not run afoul of local, state, or federal nondiscrimination enactments. Similarly, if an adherent of Islam operates a bodega, but declines to stock and sell any pork products, that decision should not be subject to second-guessing by the government. Simply put, not offering a particular good or service to anyone is not stigmatizing in the same way as targeted denials of access to goods and services and, therefore, should be entirely lawful even for a business open to the general public.

(for ex: race $w$ circum govern signific not typ

State whethe instrun holistic that wi. its cor? runnin

The bound: of prive tions a] with ne The les autono racial t

In th when $t$ more g

68 See R Meta

69 See B cout: state : of a st that" cast th accur

to Brent (obse1 lack r the $b c$ may $\mathrm{t}$ U.S. of the 68 , at actior jettiso actior indivi persol 
(for example, encouraging private property owners to discriminate on the basis of race when selling or renting real property), and whether, in the totality of the of service vice taken to invoke ;ociation's ion law. ${ }^{66}$ picks and tion? 'The contextual a "public" motes the

ne resem1 , contextostensibly ns on the activity at for public tity?), the Jffee shop in ground ivernment regulation circumstances, the ostensibly private entity is sufficiently "entwined" with the government to render it an alter ego of the state (does the government have a significant measure of control over the entity and lend it targeted forms of support not typically provided to nongovernmental institutions?). ${ }^{68}$

State action analysis is highly fact-specific and relies on context - including whether a reasonable observer would perceive the ostensibly private entity as an instrument of the state itself. ${ }^{69}$ It also bears noting that state action rules, although holistic and highly contextual, are sufficiently clear and predictable that an entity that wishes to avoid the risk of state actor status can easily do so by carefully limiting its connections with the government and avoiding undertaking tasks, such as running a prison or tax collection, that are the exclusive prerogatives of the state.

The state action doctrine exists to ensure that government does not slip the bounds of constitutional constraints, but it also seeks to preserve and protect a sphere of private autonomy, a realm that exists free and clear of the constitutional limitations applicable to the government. ${ }^{70}$ In the context of reconciling religious liberty with nondiscrimination principles, the objectives are quite similar, but not identical. The legal system should seek simultaneously to safeguard a realm of private religious autonomy and also to ensure that a dollar may be spent as easily in an LGBT or racial minority person's hands as in anyone else's.

In this regard, it bears noting that complicity claims generally should be rejected when based on religious motives, just as the Supreme Court has rejected them in a more generalized First Amendment context. In Rumsfeld v. Forum for Academic and

${ }^{68}$ See Ronald J. Krotoszynski, Jr., Back to the Briarpatch: An Argument in Favor of Constitutional Meta-Analysis in State Action Determinations, 94 Мich. L. REv. 302, 314-21, 337-46 (1995).

69 See Burton v. Wilmington Parking Auth., 365 U.S. 715, 722 (1961) (holding that the federal courts must "sift facts" and "weigh circumstances" in order to ferret out "nonobvious" forms of state action); see also Krotoszynski, supra note 68, at 334-37, 342 (emphasizing the importance of a searching and contextual analysis when making state action determinations and observing that "[o]nly by expanding the state action inquiry - thereby requiring the lower federal courts to cast their analytical nets more broadly - can actions 'fairly attributable to the State' be identified accurately").

$7^{\circ}$ Brentwood Acad. v. Tennessee Secondary Sch. Athletic Ass'n, 531 U.S. 288, 295-96 (2001) (observing that "[w] hat is fairly attributable is a matter of normative judgment, and the criteria lack rigid simplicity" and holding that "no one fact can function as a necessary condition across the board for finding state action; nor is any set of circumstances absolutely sufficient, for there may be some countervailing reason against attributing activity to the government"); Burton, 365 U.S. at 722 ("Only by sifting facts and weighing circumstances can the nonobvious involvement of the State in private conduct be attributed its true significance."); see Krotoszynski, supra note 68 , at 335,346 (noting that the state action doctrine "preserves a sphere of individual freedom of action, a freedom of action that would be reduced significantly were the Supreme Court to jettison the doctrine in favor of some sort of ad hoc rights balancing" and positing that the state action doctrine "permits courts to hold government accountable and protects the freedom of individual citizens to make fundamental decisions about their economic, social, religious, and personal relationships"). 
Institutional Rights, Inc. (FAIR), ${ }^{71}$ the Supreme Court unanimously held that FAIR's claim that permitting military recruiters on campus forced them to be complicit in discrimination against gay and lesbian persons lacked merit. ${ }^{72}$ The law schools comprising FAIR had argued that permitting the military to interview on campus, when the "Don't Ask, Don't Tell" policy was in effect, would violate their polices against discrimination based on LGBT status and render them complicit in such discrimination. In this context, however, the deeply held conviction that discrimination against LBGT persons is morally wrong had little, if any, traction. Chief Justice John G. Roberts, Jr., squarely rejected the complicity argument - as did all of the other justices.

The Supreme Court characterized the mandatory access provision as a regulation of conduct and a condition of government largesse - which a university could elect to reject if it wished to avoid the conduct regulation. ${ }^{73}$ As Chief Justice Roberts put it, "a law school's decision to allow recruiters on campus is not inherently expressive" because "[a] law school's recruiting services lack the expressive quality of a parade." 74 The law schools had "overstate[d] the expressive nature of their activity" in a failed "attempt[ ] to stretch a number of First Amendment doctrines well beyond the sort of activities these doctrines protect." 75 A law school's accommodation of a military recruiter "is not compelled speech because the accommodation does not sufficiently interfere with any message of the school. ${ }^{76}$ The logic of this position seems apropos in the context of commercial businesses - selling a good or service on a nondiscriminatory basis does not constitute forced speech, at least when the regulated enterprise generally holds itself out as open to any and all comers. ${ }^{77}$

Consider, too, that universities, going back to Keyishian v. Board of Regents ${ }^{78}$ and Sweezy v. New Hampshire, ${ }^{79}$ enjoy special First Amendment status as institutions; academic freedom is a well-established penumbra of the First Amendment. Thus,

71547 U.S. 47 (2006).

$7^{2}$ Id. at $69-70$.

73 Id, at 64 .

$74 \mathrm{Id}$.

75 Id, at 70 .

$76 \mathrm{Id}$. at 64

77 Caroline Mala Corbin, Speech or Conduct? The Free Speech Claims of Wedding Vendors, 65 EMORY L.J. 241, 244-57, 267-74, 297-301 (2015) (arguing that the sale of goods and services constitutes conduct rather than speech and usually lacks significant expressive context or meaning).

$7^{8} 385$ U.S. $589,603(1967)$ ("Our Nation is deeply committed to safeguarding academic freedom, which is of transcendent value to all of us and not merely to the teachers concerned. That freedom is therefore a special concern of the First Amendment, which does not tolerate laws that cast a pall of orthodoxy over the classroom.").

79354 U.S. 234, 250 (1957) ("The essentiality of freedorn in the community of American universities is almost self-evident. No one should underestimate the vital role in a democracy that is played by those who guide and train our youth.").

althou

sess $\mathrm{sP}$

in casi

off FA

Acade

Amenı

In ,

compl

person

heavy

by the

the be

too by

statute

not spr

wheth،

respect

To

exclusi

activity

afternc

prograu

prograu

So Hoog

affiliá

B. See F

${ }^{8} \mathrm{~A}$ See, $\mathrm{E}$

the it

assoc

tutior

${ }_{3}$ See, 6

st Kroto

85 See C

the $c$

condi

on " $c$

publi.

244-5

precis

86 The $\mathrm{f}$

Faith

absen

applic

entity

U.S.

rondi 
ssly held that 1 them to be merit. $^{72}$ The o interview on $\mathrm{d}$ violate their a complicit in snviction that any, traction. argument - as

in as a regulariversity could Chief Justice ampus is not ıck the expresressive nature t Amendment ect."75 A law reech because essage of the of commercial sasis does not enerally holds

${ }^{-}$Regents $^{78}$ and as institutions; idment. Thus, although most universities are not religious entities, ${ }^{8 \circ}$ universities nonetheless possess special First Amendment status as institutions ${ }^{81}$ - a point repeatedly recognized in cases such as Bakke, Southworth, and Grutter. ${ }^{82}$ Thus, one cannot simply waive off FAIR on the proposed distinction that the belief at issue was not religiously based. Academic freedom, no less than religious freedom, enjoys a zone of enhanced First Amendment protection. ${ }^{83}$

In consequence, crediting "complicity" as a sound legal basis for excusing compliance with a conduct-based rule (i.e., that you cannot refuse service to a person based on their status) in one context, but not in another, constitutes a rather heavy jurisprudential lift. Just as a law school that accepts federal funds must abide by the conditions that attach to receipt of those funds, a business owner that wants the benefit of participating in the public marketplace cannot have its cake and eat it too by refusing to play by the rules that govern the agora. ${ }^{84}$ Public accommodation statutes, as Professor Caroline Mala Corbin argues persuasively, regulate conduct, not speech. ${ }^{85}$ As such, the holding of FAIR ought to be controlling with respect to whether mandatory nondiscrimination rules can be adopted and enforced with respect to commercial businesses open to the public.

To be sure, a balancing excrcise is necessary - a balance that involves how exclusionary ("private") the entity in question happens to be and how related the activity is to its core religious activities. We should not be regulating a madrassa's afternoon day care operation because it excludes nonbelievers or sex-segregates its program. ${ }^{86}$ But, a Denny's restaurant simply is not the same as a mosque's day care program.

8o Hoogstra et al., Chapter 25, note that roughly one in four colleges and universities is religiously affiliated.

81 See Paul Horwitz, First Amendment Institutions 86-87, 107-41, 234-35 (2013).

${ }^{82}$ See, e.g., Grulter v. Bollinger, 539 U.S. $306,329(2003)$ ("We have long recognized that, given the important purpose of public education and the expansive freedoms of speech and thought associated with the university environment, universities occupy a special niche in our constitutional tradition.").

${ }^{8}$ See, e.g., Garcetti v. Ceballos, 547 U.S. 410, 425 (2006); id. at 438-39 (Souter, J., dissenting)

${ }^{84}$ Krotoszynski, Agora, supra note 57 , at $1235-40$.

${ }^{85}$ See Corbin, supra note 77 , at $273-74$ ("In analyzing the conduct versus speech distinction in the context of services provided by a business open to the public, it would appear that conducting a commercial transaction is ultimately conduct."). Professor Corbin's emphasis on "commercial" businesses that are generally "open to the public" demonstrates that the public character of the enterprise is plainly playing an important role in her analysis. See id. at 244-57, 267-74, 297-301. Her reliance on the belief/conduct distinction has persuasive force precisely because the kind of business that she describes is not private in character.

${ }^{86}$ The fact that an entity could exclude does not mean that it must exclude. If an extension of a faith community's religious activities chooses to open itself up to the general public, even absent a legal obligation to do so, it arguably should be subject to govemment regulations applicable to a "public" entity. For example, a private dining club may operate as a "private" entity and exclude nonmembers. See New York State Club Ass'n, Inc. v. City of New York, $4^{87}$ U.S. 1, 12-14 (1988) (rejecting a facial challenge to the application of New York City's nondiscrimination ordinance to certain large private dining clubs "because of the kind of role 
In short, the state ought to be able to require that a business open to the public serve all comers - much as ferries, inns, and toll roads subject to licensure requirements and tariff regulation were required to serve anyone who could pay the posted rate. ${ }^{87}$ On the other hand, however, if a ferryman wishes to festoon his ferryboat with an image of the Virgin Mary, or an innkeeper hangs a picture of Dürer's praying hands above the inn's check-in desk, such public expressions of belief should lie beyond the legitimate reach of government regulation. Belief must encompass the ability to communicate religious convictions and commitments to others in the community - even if some find these convictions upsetting, discriminatory, or offensive. This result obtains because the ability to share a belief with others is integral to holding a belief. And, actions motivated by belief do not cease to be beliefs.

\section{CONCLUSION}

The devil really is in the details. The United States needs clear rules that predictably and reliably reconcile nondiscrimination rulcs with claims of religious liberty - but clear rules seem highly elusive in this context. The Commission's approach, however, fails to give adequate scope or sweep to "belief" and seeks to subject to pervasive government regulation the expression of sincerely held religious beliefs that happen to occur in public places and spaces. This line of demarcation cuts too deeply into the realm of private religious practice and would subject self-constituted communities of taith to an unacceptably high level of government regulation. ${ }^{88}$ A better approach would attempt to create and deploy a legal taxonomy that characterizes particular institutions and enterprises as either public or private in nature and then makes accommodations available to the latter - but not to the former.

To be sure, the public/private distinction is not a perfect solution. Important details will still need to be worked out to operationalize it to separate valid and invalid claims to exemptions from public accommodation laws, whether under statutes, like the RFRA, or directly under the Free Exercise Clause itself. Despite the dichotomy's shortcomings, however, it seems a more promising general framing

that strangers play in their ordinary existence" and the voluntary maintenance of operating practices that belied a plausible constitutional claim that these entities were truly private rather than "nonprivate" in nature). However, if the enterprise seeks to augment its revenue by serving a large number of nonadherents, it risks losing its First Amendment-based shield against pervasive government regulation of its operations. See id. at 11-14, 18. In consequence, if the ability to exclude is actually important to the raison d'etre of a faith community's affiliated enterprise, then that enterprise should exclude nonbelievers and not operate on an open-to-allcomers basis.

87 See The Civil Rights Cases, 109 U.S. 3, 37-43 (1.883) (Harlan, J, dissenting).

88 INAZU, supra note 39 , at $185-86$ (arguing for the protection of self-constituted groups that "com[e] together in a way of life"). 
Iblic

iire-

isted

with

ying

d lie

s the

I the

$y$, or

Is is

o be

stably

- but

how-

sct to

seliefs

ts too

ituted ion. $^{88}$

$y$ that ate in to the

rortant $\mathrm{d}$ and under lespite aming

device than the belief/conduct dichotomy or a focus on potential third-party harms. In sum, a workable test must provide for a balancing of the relative equities in a context-specific way and the public/private distinction provides a potentially workable framing device for undertaking this analysis.

Aristotle admonishes that virtue often consists of the mean between two extremes. ${ }^{89}$ For example, courage constitutes the virtuous mean between the two extremes of being cowardly or foolhardy. So, too, magnanimity represents the virtuous mean between the extremes of being a miser or a spendthrift. Peaceful coexistence can be achieved only if we find and hold the "virtuous mean" between the vicious extremes of unlimited exemptions from nondiscrimination laws and the mindless application of such laws to essentially private activity that bears a close nexus with the existence and maintenance of a self-constituted community of faith.

${ }^{89}$ Aristotle, Nicomachean Ethics 1106a5-1109b (Terence Irwin trans., Hackett Pub. Co. 1985). For a relevant discussion of Aristotle's concept of the virtuous mean, see Dan M. Kahan \& Martha C. Nussbaum, Two Conceptions of Emotion in Criminal Law, 96 Colum. L. Rev. 269 , 286-88 (1996). 